\title{
Absinthe, Absinthism and Thujone - New Insight into the Spirit's Impact on Public Health
}

\author{
Dirk W. Lachenmeier ${ }^{*}, 1$, David Nathan-Maister ${ }^{2}$, Theodore A. Breaux ${ }^{3}$, Jean-Pierre Luauté ${ }^{4}$ and \\ Joachim Emmert ${ }^{5}$
}

\author{
${ }^{I}$ Chemisches und Veterinäruntersuchungsamt (CVUA) Karlsruhe, Weissenburger Strasse 3, D-76187 Karlsruhe, \\ Germany \\ ${ }^{2}$ Oxygenee Ltd, P.O. Box 340, Burgess Hill, RH15 5AP, UK \\ ${ }^{3}$ Jade Liqueurs, L.L.C., 3588 Brookfield Rd, Birmingham, Alabama, 35226, USA \\ ${ }^{4} 25$ Rue de la République, 26100 Romans, France \\ ${ }^{5}$ Perreystrasse 34, D-68219 Mannheim, Germany
}

\begin{abstract}
Absinthe, a strong alcoholic aperitif, is notorious for containing the compound 'thujone', which has been commonly regarded as its 'active ingredient'. It has been widely theorized that the thujone content of vintage absinthe made it harmful to public health, and caused the distinct syndrome absinthism, which was extensively described in the literature prior to the spirit's ban in 1915. The interdisciplinary research presented in this paper shows that 1) absinthism cannot be distinguished from common alcoholism in the medical research literature of the time, and that 2) due to the physical chemistry of the distillation process, the thujone content of vintage absinthe was considerably lower than previously estimated and corresponds to levels generally recognized as safe, as proven by analyses of absinthes from the pre-ban era. Due to the re-legalization of absinthe in the European Union and more recently in the United States, potential public health concerns have re-emerged, not expressly based on worries about thujone content or absinthism, but on alcohol-related harm and youth protection issues, exacerbated by marketing strategies promoting absinthe using false and discredited claims pertaining to thujone and stubbornly persistant myths.
\end{abstract}

Keywords: Absinthe, absinthism, thujone, alcohol, ethanol, alcoholic beverages, spirits, alcohol abuse, alcohol-related disorders.

\section{INTRODUCTION}

Absinthe is a strong alcoholic aperitif traditionally distilled from alcohol and herbs or cold-compounded from herbal extracts, chief amongst them common or 'grande' wormwood (Artemisia absinthium L.), green anise (Pimpinella anisum L.) and Florence fennel (Foeniculum vulgare Mill.), but also most often including three other herbs: Roman or 'petite' wormwood (Artemisia pontica L.), hyssop (Hyssopus officinalis L.), and melissa or lemon balm (Melissa officinalis L.).

The popular belief about absinthe is that it is an illicit drug, or at least is possessive of qualities that render it similar to such drugs in effect. Central to this belief is a substance called 'thujone' (Fig. 1), which is a natural constituent of Artemisia sp., and usually regarded as its 'active' ingredient. Thujone was said to be harmful to public health, causing 'absinthism', a syndrome distinct from alcoholism, characterized by epileptic fits and rapid mental and physical deterioration.

*Address correspondence to this author at the Chemisches und Veterinäruntersuchungsamt (CVUA) Karlsruhe, Weissenburger Strasse 3, D-76187 Karlsruhe, Germany; Tel: +49-721-926-5434; Fax: +49-721-9265539; E-mail: Lachenmeier@web.de
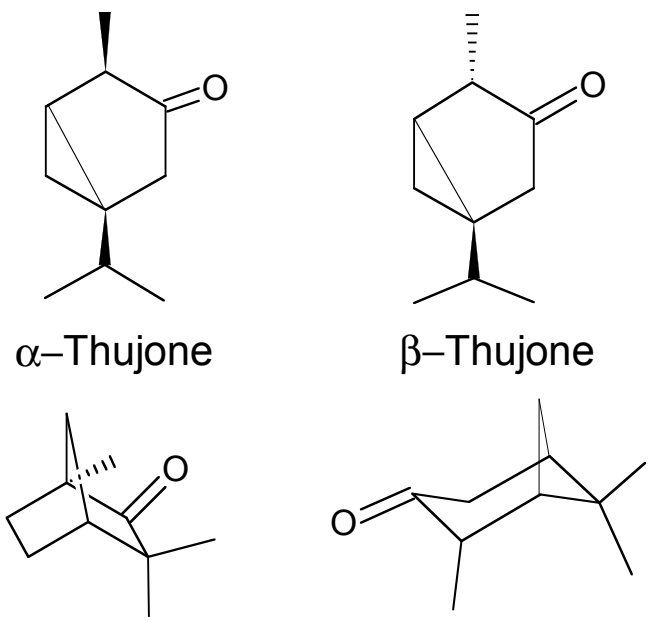

Fenchone

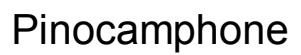

Fig. (1). Chemical structures of terpenes naturally occurring in absinthe: thujone from wormwood, fenchone from fennel, and pinocamphone from hyssop.

In this article, the authors systematically study these prejudices about absinthe, and provide scientific evidence from a multidisciplinary perspective to explain the popular misconceptions that absinthe caused hallucinations, drove 
men 'mad', threw them into epileptic fits, and even made van Gogh slice off his ear.

\section{HISTORY OF ABSINTHE}

High quality absinthes are always distilled from whole herbs rather than compounded from commercial essences, and have a deliciously complex herbal and floral character, with an underlying bitterness contributed by the wormwood(s). Well-made absinthes are naturally colored and generally pale green, but 'louche', or turn milky, when water is added. This is caused by the essential oils precipitating out of the solution as the alcohol is diluted. Clear absinthes - often referred to as 'La Bleue' or 'La Blanche', are historically popular in Switzerland, and are crafted without the final coloring step $[1,2]$.

While infusions of wormwood date back to Roman times and earlier [3], the specific green-tinged distillation of wormwood, anise and fennel that constitutes the modern liquor absinthe seems to have originated in western Switzerland in the second half of the $18^{\text {th }}$ century. Legend has it, that the inventor of the drink was Dr. Pierre Ordinaire, who in the 1780's, shortly before the French revolution, travelled around the Val de Travers near Couvet in Switzerland, and produced the first distilled absinthe, initially as an all-purpose remedy or cure-all. It would eventually be nicknamed 'La Fée Verte' - 'The Green Fairy' - and this name stuck throughout absinthe's heyday. While credence is generally given to the legend of Dr. Ordinaire, more recent research has uncovered multiple references to the liquor in regional records from at least the 1760's onwards, and it seems more probable that Dr. Ordinaire was simply an enthusiastic early advocate of the drink, rather than necessarily its original creator. Absinthe was recommended for the treatment of epilepsy, gout, kidney stones, colic, headaches and worms. Dr. Ordinaire's absinthe recipe aroused the interest of a gentleman named Major Dubied, who saw its possibilities not just as a patent medicine, but as an apéritif. Dubied purchased what was reputed to be Ordinaire's original formula at the beginning of the 19th century and began commercial production [4]. An original 1794 recipe for absinthe is shown in Fig. (2) [5].

By 1805, the Pernod Fils absinthe company was set up in Pontarlier in the Doubs region, and run by Dubied's son-inlaw, Henri-Louis Pernod. Initially there were just two stills producing only 16 liters of absinthe per day, but Pernod Fils very soon went from strength to strength. By 1850 , when Louis died, the factory had 26 stills producing 20,000 liters per day [6].

The popularity of absinthe spread further as it was used as a fever preventative by French troops fighting in Algeria from 1844 to 1847. Mixed with wine or water it was believed to kill germs and fend off dysentery. When the troops of the Bataillon d'Afrique returned to France, they brought with them their taste for the refreshingly bitter drink, and absinthe became popular in bars and bistros all over France [4]

Licensing laws were relaxed during the 1860's, which resulted in a proliferation of new bars, cabarets and cafés more than 30,000 existed in Paris by 1869, and 5 p.m. signified 'l'Heure Verte' - 'the Green Hour' - in almost every one. The cafés were an extremely popular place to socialize, since most of Paris' citizens were living in cramped apartments, often in squalor and poverty [4].

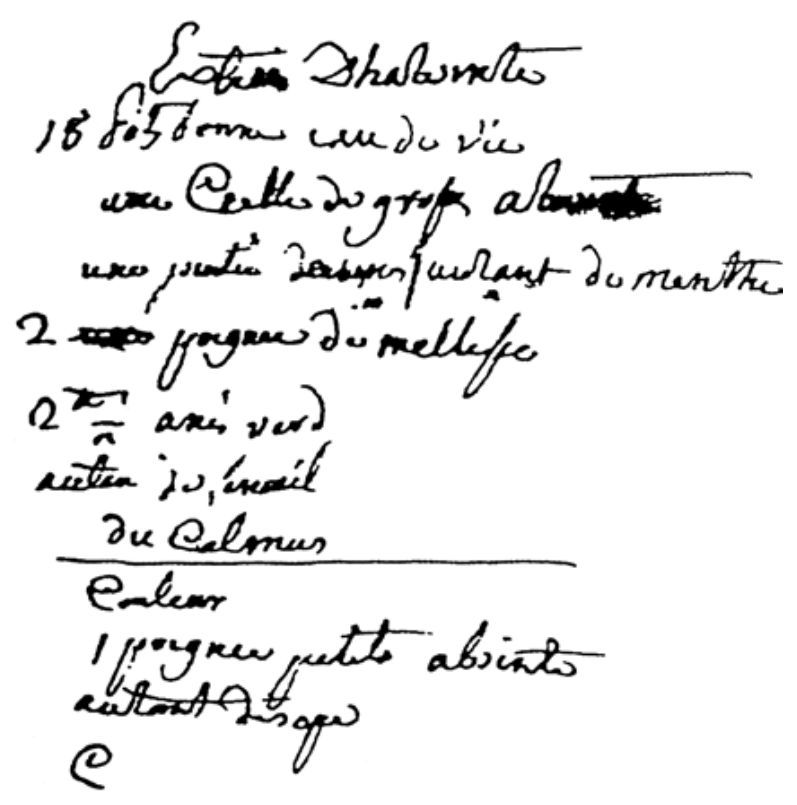

Fig. (2). Original 1794 recipe of absinthe. For 18 pots of eau-de-vie (approximately 34 litres), a large bucket of common wormwood (Artemisia absinthium), some mint, two handfuls of lemon balm and two of green anise, the same amount of fennel, some calamus. To colour: a handful of roman wormwood (Artemisia pontica) and the same amount of hyssop (Reproduced with permission from Delachaux [5]).

Absinthe hit its peak during the years from 1880-1910, when it fell dramatically in price, becoming accessible to all parts of society and rivaling wine as the most popular drink in France. In the 1870's phylloxera had ravaged the vineyards of France, substantially increasing the cost of wine, and opening the door to the widespread use of lower cost alcohols derived from sugar beet or grain in the production of absinthe. This lowering of production costs, coupled with increased demand due to the shortage of wine, was the reason behind the explosive growth in popularity of the drink, but also sowed the seeds of its downfall. In 1874 , France consumed 700,000 liters of absinthe, but by 1910, the figure had exploded to 36,000,000 liters of absinthe per year. It was a quintessential part of Belle Époque French society [4].

In the 1860 's, there was for the first time concern about the results of chronic abuse of absinthe. Chronic use of absinthe was claimed to produce a syndrome, called 'absinthism', which was characterized by addiction, hyperexcitability, epileptic fits and hallucinations [7].

\section{ABSINTHISM WAS MISDIAGNOSED ALCOHOLISM}

The first report describing absinthism as a syndrome distinct from alcoholism appeared in 1859 in the doctoral thesis 'Considerations Générales sur l'Alcoolisme, et plus particulièrement des Effects Toxiques Produits sur l'Homme par la Liqueur d'Absinthe' by Auguste Motet [8]. 
The characterisation of absinthism as a distinct syndrome was further developed by the eminent French researcher Dr Valentin Magnan, the chief physician at the asylum of Sainte-Anne in Paris, in a series of influential papers [9]. Magnan attributed the epileptic seizures and general delirium observed in long term absinthe drinkers to wormwood essence in absinthe in particular, rather than to alcohol in general [10]. A historical survey [9] showed that Magnan was swayed by specific anecdotal reports from which he inferred the general principle. Magnan's convictions were further supported by the discovery he made, while serving as an intern under L.-V. Marcé, on the highly convulsive effect of the essential oil of wormwood on animals [10]. Fig. (3) shows a satirical drawing of such animal experiments. The results of their experiments gained renown as they were presented by Marcé and read by Claude Bernard himself [11]. Although Magnan was a firm supporter of the doctrine of 'médecine expérimentale', the clinical confirmation he drew ignored the fact that the actual concentration of wormwood essential oil in traditionally distilled absinthe was small. Matters were not helped by semantic confusion Anglophones generally use the word 'wormwood' when referring to the plant or its essential oil, and the word 'absinthe' when referring to the alcoholic aperitif. In French, 'absinthe' refers to the plant and its oils, and/or the drink. So experimental results directly related only to wormwood oil were, in the popular mind, easily confused as referring to the popular aperitif itself [7]. Magnan further used clinical observations of dogs treated with absinthe oil to infer, as in humans, the presence of hallucinations. Magnan's allegations about absinthe were immediately challenged in France and particularly in England, but the distinction between the effects of absinthe and of alcohol in general remained for him indisputable. In 1874 he published an English article in the Lancet expounding upon his views [12]. Magnan, who was widely eminent in his field - he is still regarded today as one of the fathers of French psychiatry - firmly battled against all critics.

Additionally, during the late $19^{\text {th }}$ and early $20^{\text {th }}$ centuries, various temperance movements were active in both France and Switzerland, all of whom targeted absinthe with particular vehemence. Due to its high alcoholic strength, rising popularity and simultaneously decreasing shelf price (with industrial, adulterated brands being seductively cheap), absinthe became an obvious poster child for the dangers of alcohol. The word 'absinthism' soon came to lose its specific meaning. Absinthism and alcoholism were confused, and alcohol dependent people were simply deemed 'absinthe drinkers'. This confusion also seems to have been deliberately encouraged by the wine-growing industry, struggling to regain market share after the ravages of phylloxera. Wine was believed to be healthy and natural, since it came from the land and was a time-honored tradition, not to mention a major source of revenue. Absinthe, however, was oftentimes made with industrial alcohol (especially the cheaper brands), and so it is no surprise that it was targeted from both the temperance movement and the wine lobby, leading to the absinthe prohibition in many European countries at the beginning of the $20^{\text {th }}$ century [4].

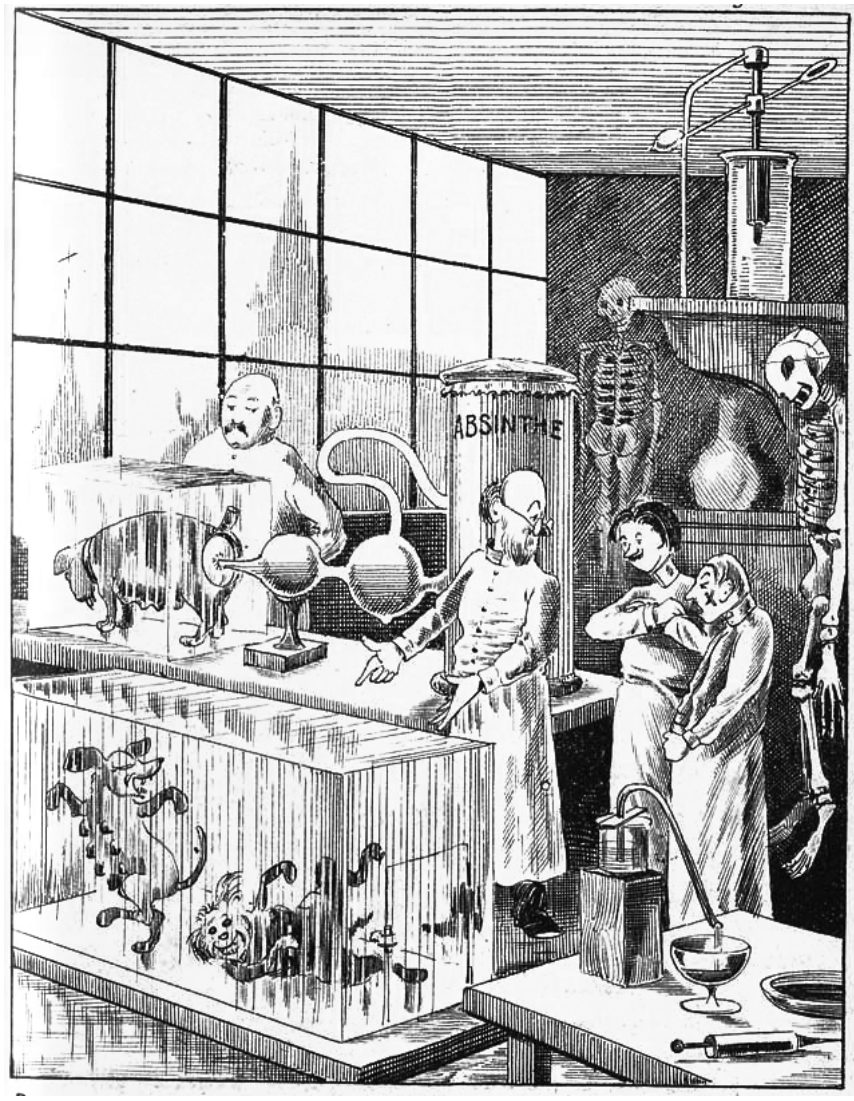

Fig. (3). Satirical drawing of the animal experiments with dogs, which were conducted for proofing the syndrome absinthism (Reproduced with permission from Nathan-Maister [4]).

\section{DISTILLATION TECHNOLOGY DISPROVES THE THUJONE CONNECTION}

Besides the lack of proof about absinthism in the medical literature $[7,9]$, the physicochemical characteristics of the distillation and manufacturing processes of absinthe have to be considered in the evaluation of thujone as potentially causative agent for absinthe's effects [13].

The production technique utilized by absinthe distillers of the Belle Époque is described in detail, both in distillers' promotional literature [14] and throughout various thirdparty treatises from the period [15]. Likewise, the equipment used for the process is described in the same texts, as well as depicted in numerous photographs of distillation salons from the most prestigious houses. In fact, some of these original pieces of equipment remain in commercial service to the present day (Fig. 4).

The basic process consists of a simple fractional redistillation that involves the use of a large pot still designed for the purpose. The procedure calls for the maceration of whole herbs in a neutral spirit (typically $85+\%$ ethanol) for a period of 12-24 hours, followed by the addition of a volume of water, which is followed by distillation. The distillate is always recovered in fractions, the heart of the distillation consisting of the perfumed spirit, and the tails consisting of unpalatable, empyreumatic phlegms (which are either recycled or discarded). And while the use of water in the pot 


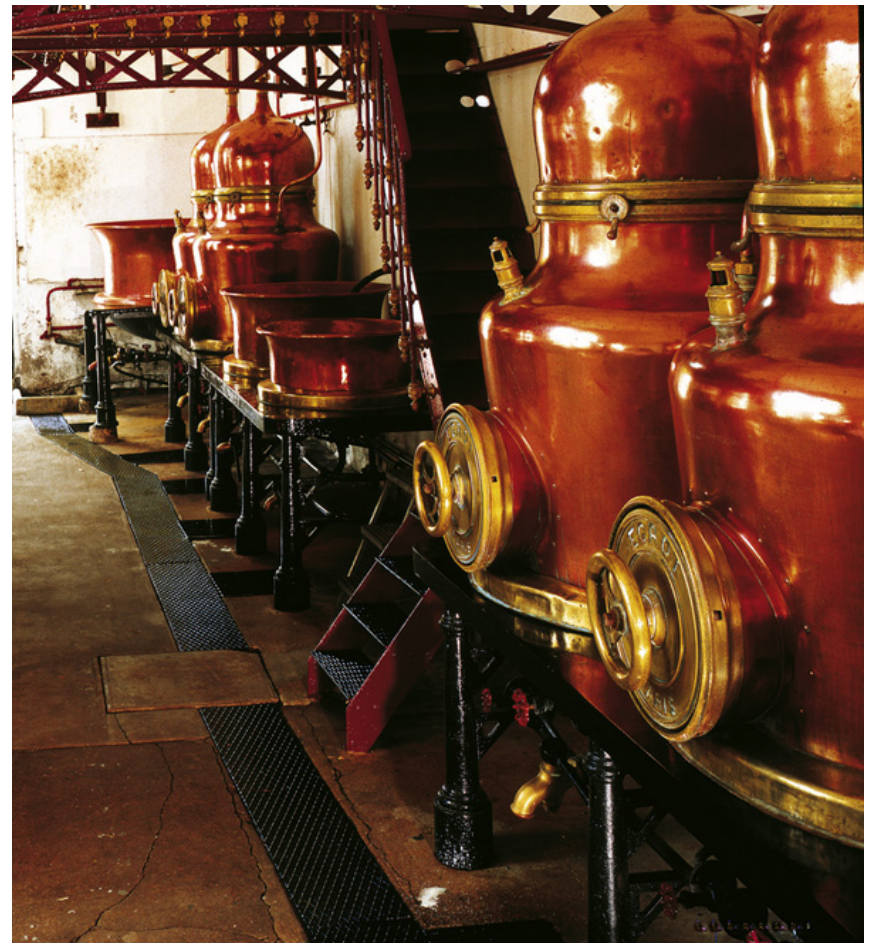

Fig. (4). The historic Combier distillery in Saumur, France, uses two original 1870 alambics for the production of modern absintherecreations.

aids in driving the distillation, the presence of ethanol causes the vapor temperatures throughout the heart of the distillation to remain relatively low, which improves the exclusivity of the process and the organoleptic quality of the product. This observation accounts for the difference in content and flavor between an absinthe prepared from the traditional spirituous re-distillation of herbs as opposed to that cold-mixed from industrial (steam distilled) essences. The lower distillation temperatures and exclusion of the phlegms from the bottled product together constitute a selective process in which a significant portion of thujone from the macerate is omitted from the distillate. Finally, the reduction from distillate strength $(\sim 80 \%$ Ethanol) to a bottled strength of $60-72 \%$ for flagship products and $45-60 \%$ for lesser grades, represents yet another significant reduction $(10-44 \%)$ in overall thujone content between the recovered distillate and the finished product. All of these effects lead to a significant reduction of thujone in the final spirit (see summary in Fig. 5), so that the thujone content can only be gathered by chemical analysis of the final beverage.

\section{CHEMICAL ANALYSIS FINALLY PROVIDES THE ANSWERS}

When most of the world's absinthe production was effectively banned (1915), the state of the art of analytical chemistry was far too primitive to clearly resolve debate regarding the actual thujone content of the liquor. By the time the analytical science became capable of resolving questions concerning the content of absinthe, the liquor (and lingering interest in it) had long since faded into obscurity. Speculation regarding the content of vintage absinthe persisted until beyond the end of the century, with published claims of thujone concentrations of up to $260 \mathrm{mg} / \mathrm{l}$ [16] commonly offered as fact and often repeated. Unfortunately, these figures were the result of extrapolations of reported herbal essential oil content, and in not one instance was data obtained through actual laboratory analysis of the finished liquor. The authors resolved some of this speculation in an earlier study, specifically by conducting a literature review on the composition of relevant species of wormwood $(A$.

\section{Thujone losses/reduction}

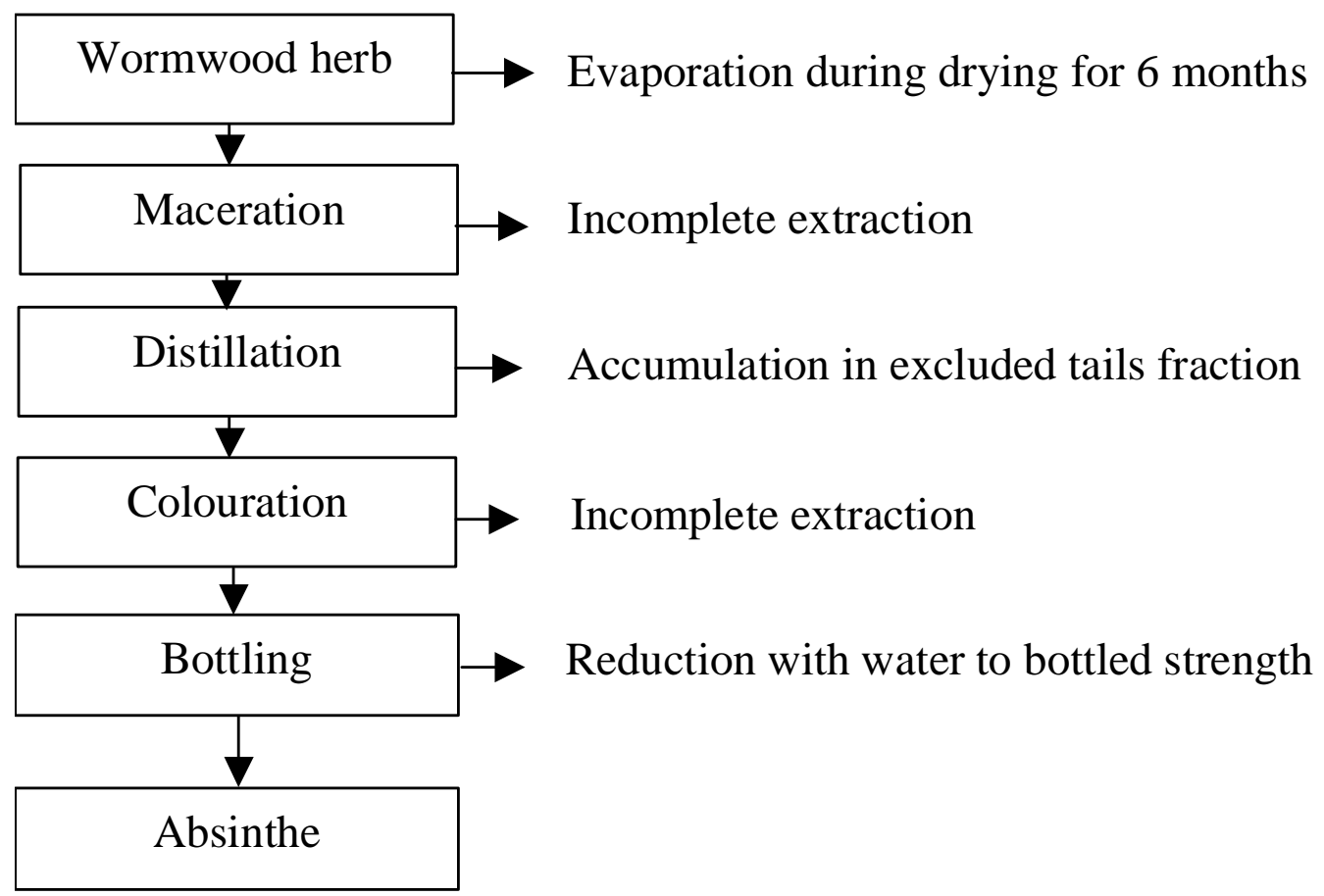

Fig. (5). Steps of absinthe production and their influence on thujone recovery. 
absinthium and A. pontica), and finding that the levels of thujone in the plants were previously overestimated [17].

The advent of gas chromatography (GC) combined with mass spectrometry (MS), and commercially available analytical standards, made it possible to develop standardized methods for the detection of thujone for regulators and researchers alike [18, 19]. Especially the use of MS as detector was helpful for the identification of thujone, when other terpenes are co-eluting (Fig. 6) [20]. Similarly, studies were conducted to resolve questions regarding the toxicity and metabolic fate of thujone isomers [21-23], which allowed researchers to gauge the actual pharmacological potential of the compound. Eventually, the last remaining question was if vintage absinthes contained a higher amount of thujone than current, similarly prepared products, and if other toxic compounds like methanol or heavy metal salts were a factor in the vintage examples. Such questions were left to debate until only recently [24]. The total thujone content in 13 analyzed pre-ban samples was found to range between 0.5 and $48.3 \mathrm{mg} / \mathrm{L}$, while the average thujone content of $25.4 \pm 20.3 \mathrm{mg} / \mathrm{L}$ fell within the modern Codex Alimentarius/European Union (EU) limit of $35 \mathrm{mg} / \mathrm{L}$ (which was derived from no-effect levels in animal experiments with an additional safety factor). The authors also provided evidence that thujone in bottled absinthe remains stable, so that our analyses of hundred-year old spirits were not confounded by significant thujone deterioration over time [25]. From an analytical viewpoint, these findings effectively exonerate absinthe of its sinister reputation.

\section{PUBLIC HEALTH POLICY ASPECTS}

The re-legalization of absinthe in Europe can be traced back to the Codex Alimentarius general requirements for natural flavorings published in 1985, which allow the use of flavorings containing thujone, up to certain maximum levels (i.e. $10 \mathrm{mg} / \mathrm{kg}$ thujone in alcoholic beverages above $25 \%$ vol and $35 \mathrm{mg} / \mathrm{kg}$ thujone in bitters) [26]. These general requirements have been introduced into the laws of many countries, including the EU [27]. The European regulation has recently been amended such that the $35 \mathrm{mg} / \mathrm{kg}$ limitation applies to all Artemisia-derived alcoholic beverages (and not only bitters) [28]. So far, the USA has not introduced the Codex Alimentarius recommendations for thujone into its law. However, a historical milestone was observed in 2007 , when the US government approved the first genuine absinthes for US distribution since 1912. The US government concluded that finished spirits that exhibit $<10$

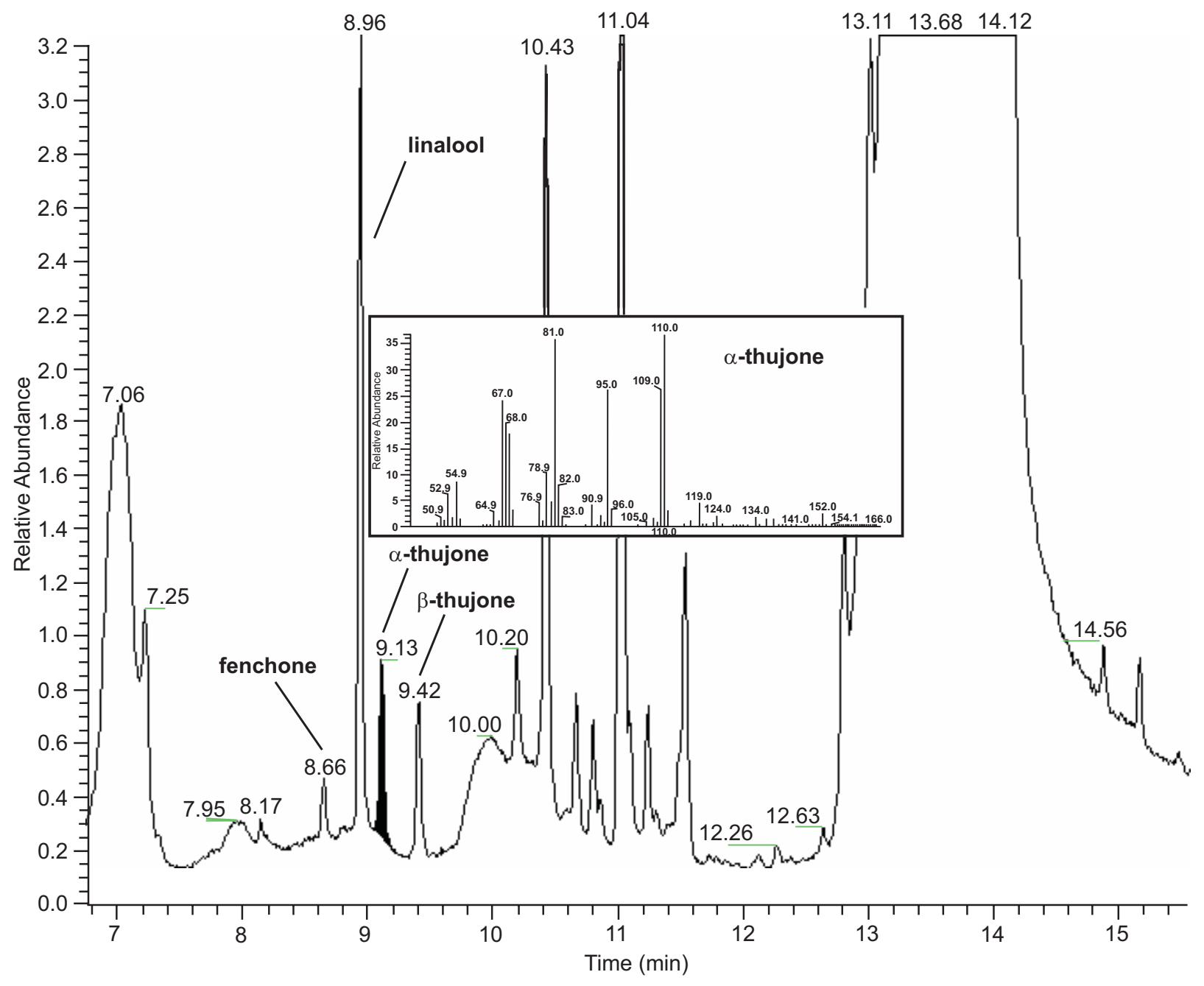

Fig. (6). GC-MS chromatogram of an absinthe sample with identification of terpenes. Insert: mass spectrum of $\alpha$-thujone. 
Table 1. Analysis Results of Spirits with the Designation 'Absinthe' Exclusively Marketed Over the Internet (Data Summarized from Löbell-Behrends et al. [31])

\begin{tabular}{|l|c|c|c|c|}
\hline & $\begin{array}{c}\text { Labeled Alcoholic } \\
\text { Strength (\% vol) }\end{array}$ & $\begin{array}{c}\text { Analyzed Alcoholic } \\
\text { Strength (\% vol) }\end{array}$ & $\begin{array}{c}\text { Labeled Thujone Content } \\
\text { Content (GC/MS) (mg/kg) }\end{array}$ \\
\hline \hline Absinthe 1 & 70 & 70.1 & $100 \mathrm{mg} / \mathrm{kg}$ (according to internet advertisement) & $126 *$ \\
\hline Absinthe 2 & (not specified) & 65.4 & 'Contains $90 \mathrm{mg}$ ' & 0.6 \\
\hline Absinthe 3 & 70 & 68.4 & $100 \mathrm{mg} / 1$ & $57 *$ \\
\hline Absinthe 4 & 70 & 54.8 & $100 \mathrm{mg} / \mathrm{kg}$ & $119 *$ \\
\hline Absinthe 5 & 55 & 54.8 & & 0.4 \\
\hline
\end{tabular}

mg/l thujone effectively satisfy the FDA's 'thujone-free' requirement $[29,30]$. This stance was adopted in accordance with the Codex Alimentarius recommendation with respect to thujone content in finished spirits, and represents not a change in the US legal code, but rather an acknowledgement that an indicated thujone content of $<10 \mathrm{mg} / 1$ is far too small to present any genuine public health concerns.

\section{CONCLUSIONS}

In conclusion, the authors want to point to a potential public health issue of greater concern than incidental thujone content, which lies in the tendency for some modern marketers to take advantage of age-old myths to promote their products as delivering an experience akin to that of illicit drugs. Many advertisements that appear both online and in print make obvious references to claimed thujone content and hint strongly of psychotropic effects beyond the ones of ethanol alone (e.g. effects similar to Cannabis) or claim alleged aphrodisiac properties for the spirit [7]. Such marketing strategies increase the appeal of these products to a younger audience, which presents far more fertile grounds for abuse. A commonly purported misconception is also the claim that thujone in absinthe acts as antagonist on the action of ethanol, so that the drinker allegedly can tolerate a higher amount of ethanol without experiencing adverse effects. This may lead to a trivialization of alcohol-related harms and could have grave health consequences, e.g. if the consumers misjudge their driving abilities.

It has become evident that a significant percentage of consumers and potential consumers want the myths about the psychotropic properties of absinthe to be true, even in the face of compelling evidence that they are not. For these consumers, absinthe, without its drug like allure, is no longer interesting. In this misapprehension they are encouraged by a handful of unscrupulous manufacturers who continue to hype the thujone myth. For example, in a recently published survey of spirits marketed under the designation 'absinthe' over the internet, thujone was detected in amounts significantly exceeding the maximum limits in three of five products purchased for analysis (Table 1). The products were advertised and intentionally manufactured for 'high-thujone content" using either pure thujone, cedar leaf oil or artificially high amounts of wormwood oil. Such unscrupulous marketers apparently use the anonymity of the internet to sell their 'drug-like' absinthes based on completely false claims [31].
Considering that many of the products in question are also significantly higher in alcohol content as compared to most commercial spirits, the potential for alcohol abuse in those seeking a drug-like experience is uncomfortably high. Already, US regulators have taken a stand against such marketing practices, and staunchly prohibit references to thujone and drug-like effects in product literature. Clearly the potential for abuse can be mitigated by a more widespread adoption of similar advertising rules by regulators in the EU, and elsewhere. These should include effective control of the sale of alcoholic beverages over the internet.

\section{REFERENCES}

[1] Lachenmeier DW, Walch SG, Padosch SA, et al. Absinthe - A review. Crit Rev Food Sci Nutr 2006; 46: 365-77.

[2] Lachenmeier DW, Frank W, Athanasakis C, et al. Absinthe, a spirit drink - its history and future from a toxicological-analytical and food regulatory point of view. Deut Lebensm-Rundsch 2004; 100 : 117-29.

[3] Bostock J, Riley HT, Eds. Pliny the Elder: Book XXVII. Chap. 28. Absinthium or wormwood. The natural history. London, UK: Taylor and Francis 1855.

[4] Nathan-Maister D. The absinthe encyclopedia. Burgess Hill, UK: Oxygéneé Press 2008.

[5] Delachaux PA. L'Absinthe au Val-de-Travers: recherches sur ses origines. Revue Historique Neuchateloise 1997; 1/97: 3-22.

[6] Couleru E. Au pays de l'absinthe, y est-on plus criminel qu'ailleurs, ou moins sain de corps et d'esprit? Un peu de statistique SVP. In the country of absinthe, are people more criminal than elsewhere or less sound in body or mind? A few statistics please. France: Montbéliard 1908.

[7] Padosch SA, Lachenmeier DW, Kröner LU. Absinthism: a fictitious 19th century syndrome with present impact. Subst Abuse Treat Prev Policy 2006; 1: 14.

[8] Motet A. Considérations générales sur l'alcoolisme et plus particulièrement des effets toxiques produits par la liqueur d'absinthe. Paris, France: Thèse pour le doctorat en médecine 1859.

[9] Luauté JP. L'absinthisme: la faute du docteur Magnan. Absinthism: the fault of doctor Magnan. Evol Psychiatr 2007; 72: 515-30.

[10] Magnan V. Accidents déterminés par l'abus de la liqueur d'absinthe. Union Med 1864; 92\&94: 227-32\&257-62.

[11] Marcé LV. Sur l'action toxique de l'essence d'absinthe. C R Acad Sci 1864; 58: 628-9.

[12] Magnan V. On the comparative action of alcohol and absinthe. Lancet 1874; 104: 410-2.

[13] Lachenmeier DW, Kuballa T. Behaviour of thujone during distillation and possible concentration ranges in pre-ban absinthe. $\mathrm{J}$ Sci Food Agric 2007; 87: 2147-51.

[14] Dentu, E. Maison Pernod Fils á Pontarlier (Doubs). Paris, France (available online: http://www.oxygenee.com/absinthe/books1.html): 1896.

[15] Duplais P. A treatise on the manufacture and distillation of alcoholic liquors - facsimile of the 1871 English edition. In: Nathan-Maister D, Ed. Burgess Hill, UK: Oxygéneé Press 2008. 
[16] Strang J, Arnold WN, Peters T. Absinthe: what's your poison? Br Med J 1999; 319: 1590-2.

[17] Lachenmeier DW, Nathan-Maister D. Systematic misinformation about thujone in pre-ban absinthe. Deut Lebensm-Rundsch 2007; 103: 255-62.

[18] Bestimmung des Thujons, gaschromatographisch. Manuel suisse des denrées alimentaires. Berne, Switzerland: Office fédéral de la santé publique 2000; vol. 32/13: pp. 1-3.

[19] Rapp A, Hastrich H, Yavas I, et al. Zur einfachen, schnellen Anreicherung ("Kaltronmethode") und quantitativen Bestimmung von flüchtigen Inhaltsstoffen aus Spirituosen: Bestimmung von Thujon, Safrol, Isosafrol, $\beta$-Asaron, Pulegon und Cumarin. Branntweinwirtsch 1994; 134: 286-9.

[20] Emmert J, Sartor G, Sporer F, et al. Determination of $\alpha-/ \beta$-thujone and related terpenes in absinthe using solid phase extraction and gas chromatography. Deut Lebensm-Rundsch 2004; 100: 352-6.

[21] Höld KM, Sirisoma NS, Casida JE. Detoxification of $\alpha$ - and $\beta$ Thujones (the active ingredients of absinthe): site specificity and species differences in cytochrome P450 oxidation in vitro and in vivo. Chem Res Toxicol 2001; 14: 589-95.

[22] Meschler JP, Howlett AC. Thujone exhibits low affinity for cannabinoid receptors but fails to evoke cannabimimetic responses. Pharm Biochem Behav 1999; 62: 473-80.

[23] Lachenmeier DW, Emmert J, Kuballa T, et al. Thujone-cause of absinthism? Forensic Sci Int 2006; 158: 1-8.

[24] Lachenmeier DW, Nathan-Maister D, Breaux TA, et al. Chemical composition of vintage preban absinthe with special reference to thujone, fenchone, pinocamphone, methanol, copper, and antimony concentrations. J Agric Food Chem 2008; 56: 3073-81.

[25] Lachenmeier DW, Nathan-Maister D, Breaux TA, et al. Long-term stability of thujone, fenchone, and pinocamphone in vintage preban absinthe. J Agric Food Chem 2009; 57: 2782-5.

[26] Codex alimentarius. General requirements for natural flavourings (CAC/GL 29.1987). 1985; www.codexalimentarius.net [Accessed on: 2007/10/17].

[27] Council Directive (EEC) No 88/388 on the approximation of the laws of the Member States relating to flavourings for use in foodstuffs and to source materials for their production. Off J Eur Commun 1988; L184: 61-6.

[28] European Parliament and Council. Regulation (EC) No 1334/2008 of the European Parliament and of the Council of 16 December 2008 on flavourings and certain food ingredients with flavouring properties for use in and on foods and amending Council Regulation (EEC) No 1601/91, Regulations (EC) No 2232/96 and (EC) No 110/2008 and Directive 2000/13/EC. Off J Eur Union 2008; L354: 34-50.

[29] FDA. Code of Federal Regulations - 21CFR172.510. 2009; www.gpoacce ss.gov/cfr [Accessed on: 2009/06/30].

[30] Alcohol and Tobacco Tax and Trade Bureau. Industry Circular Number 2007-5. Use of the term absinthe for distilled spirits. 2007; http://www.ttb.gov/industry_circulars/archives/2007/07-05.html [Accessed on: 2009/06/30].

[31] Löbell-Behrends S, Kuballa T, el-Atma O, et al. Internet marketing and the advertisement of alcoholic beverages: a failure of industry self-regulation? Sucht 2008; 54: 346-53.

(C) Lachenmeier et al.; Licensee Bentham Open.

This is an open access article licensed under the terms of the Creative Commons Attribution Non-Commercial License (http://creativecommons.org/licenses/by$\mathrm{nc} / 3.0 /$ ) which permits unrestricted, non-commercial use, distribution and reproduction in any medium, provided the work is properly cited. 